\title{
Chemical Characterization and Acceptability of Eight Cassava Varieties Introduced in Rwanda
}

\author{
Marguerite Niyibituronsa ${ }^{1}$, Jean Bosco Shingiro ${ }^{1}$, Madjaliwa Nzamwita ${ }^{2}$, Lea Ndilu ${ }^{1}$, Gerardine \\ Nyirahanganyamunsi ${ }^{1}$, Gregoire Hagenimana ${ }^{1}$, Concilie Nyirahorana ${ }^{1}$, Severin Ntivuguruzwa ${ }^{1}$, Parfait Gasana ${ }^{1}$, \\ Illuminee Kamaraba ${ }^{1}$, Usabyembabazi Madeleine ${ }^{3}$, Elvis Nkundanyirazo ${ }^{3}$, Gervais Gashaka ${ }^{1}$, Jean Claude \\ Izamuhaye $^{1}$, Charles Bucagu ${ }^{1}$, Athanase Nduwumuremyi ${ }^{1}$ \& Patrick Karangwa ${ }^{1}$ \\ ${ }^{1}$ Rwanda Agriculture and Animal Resources Development Board (RAB), Huye, Rwanda \\ ${ }^{2}$ International Institute of Tropical Agriculture (IITA), Kigali, Rwanda \\ ${ }^{3}$ Post-Harvest and Agribusiness Support Project (PASP), Kigali, Rwanda \\ Correspondence: Marguerite Niyibituronsa, Rwanda Agriculture and Animal Resources Development Board, \\ Rwanda, P.O.BOX 5016, Kigali, Rwanda. Tel: 250-788-848-200. E-mail: niyibituronsam@ gmail.com
}

Received: December 31, 2020

Accepted: February 11, $2021 \quad$ Online Published: March 29, 2021

doi:10.5539/jfr.v10n3p1

URL: https://doi.org/10.5539/jfr.v10n3p1

\begin{abstract}
Cassava is a staple food and an important and cheap source of carbohydrate in Rwanda. However, the nature and chemical composition of cassava roots limit its proper use as food due to its toxicity and short shelf life. The cyanogenic glucosides found in the cassava roots are responsible for the toxicity. The aim of the study was to characterize the chemical profile and consumer acceptability of paste from eight cassava varieties processed into flour using four processing methods. The cassava samples were harvested from trials conducted at Rubona Station of Rwanda Agriculture and Animal Resources Development Board. Four processing methods were used, namely, Cassava grated fermented, Cassava roots fermented, Cassava grated no fermented and Cassava roots no fermented. Pressing was done before drying the products to obtain the flour. At each stage of processing, the samples were prepared for laboratory analysis of dry mater, titratable acidity, cyanhydric acid and crude fiber by Rwanda Standards Board laboratory. Cassava flour was made into paste and sensory evaluation was conducted to evaluate the acceptability of the eight cassava varieties. The sensory attributes for the Ugali tested was significantly different $(\mathrm{P}<0.05)$. The method of grating before fermentation gave the most tasty Ugali than cassava root fermented. The more prefered varieties were GAHENE/2 and SEMAK 150/452 followed by BULK 13, MH95/0091 and NASE 14. The chemical analysis done for the 8 cassava varieties flour from the 4 processing methods exhibited the acceptable acidity and the NASE 14, Gahene/2 and Bulk 13 had the lowest cyanide hydrogen.
\end{abstract}

Keywords: Cassava, Cyanide, dry mater, sensory attributes, titratable acidity

\section{Introduction}

Cassava is among the important staple crops in Rwanda. It is one of the priority crops supported by the Government of Rwanda under the crop intensification program (CIP). It is mainly grown by small holder farmers in major cassava producing regions of Rwanda. Cassava is important because it is used as a source of food for human consumption and non-food products such as animal feed, ethanol for biofuel and starch for different industries (Wangpor et al., 2017; Quaye, 2009). Cassava root is a high energy food with a considerable amount of water and carbohydrates. On fresh weight basis, the roots contain 60 to $65 \%$ moisture and 30 to $35 \%$ carbohydrates (Breuninger et al., 2009; Balagopalan et al., 1988). However, cassava roots are poor sources of proteins and minerals (Montagnac et al., 2009).

Although cassava is important for food security, the nature and chemical composition of cassava roots limit its proper use as food due to its toxicity and short shelf life. Hence, processing is key to eliminate or reduce toxicity, improve palatability and preservation (Uyoh et al., 2009; Oyewole, 1995). The level of cyanogenic glucosides classifies cassava into sweet varieties when the level is low, and bitter varieties when the level is high (Falade and Akingbala, 2010). However, the toxicity must be removed to the acceptable or safe levels by using different detoxification methods. Various processing methods are used, and their efficiency to remove toxicity is 
determined by the levels of cyanide residues remained in the finished product (Breuninger, et al., 2009). The cyanogenic glucosides found in all parts of the cassava plant including the edible roots, are responsible for the toxicity (Breuninger, et al., 2009) when they are converted into hydrogen cyanide (Møller, 2010). Falade and Akingbala (2010) reported that cassava roots contain various levels of cyanide ranging between 31 and 630 $\mathrm{ppm} / \mathrm{kg}$ of fresh cassava roots. However, the intensity varies considerably depending on variety, climate and environmental conditions. To get high quality cassava flour, the roots are processed through fermentation process by either dry or wet method. A wet natural fermentation is a common method in Rwanda, consisting of immersing either whole or grated fresh roots in water which are fermented by wild bacteria from the environment for 2 to 5 days (Oyewole, 1995). Wet fermentation of cassava involves various microorganisms including Bacillus spp, Leuconostoc spp, Klebsiella spp, Corynebacterium spp, Lactobacillus spp, Aspergillus spp, Candida spp and Geotrichum spp (Oyewole, 1995). Detoxification should be maximized to produce high quality flour that meets quality requirements in terms of physico-chemical, microbial and safety characteristics, since the quality is a measure of consumer acceptability.

The quality of cassava flour is affected by various factors including the chemical composition of cassava root, unit operations and processing method used. Different cassava varieties show different chemical profiles, hence different flour quality. The color of cassava flour varies depending on the variety. For example, bitter cassava roots give whitish flour, while yellow fleshed roots give off-white color (Taofik et al., 2016). Cassava root is rich in starch which is a significant quality parameter for flour. For example, the ratio of amylose/amylopectin in starch affects the texture of cassava paste and other end products. The choice of processing unit operation highly contributes to flour quality. For example, the sizes of cassava roots or slices affect the rate of fermentation and later the quality of flour (Oyewole, 1995), since size reduction increases the surface area for rapid removal of the acid and rapid drying (Quaye et al., 2009). Chipping of fresh roots was reported to reduce cyanoglycosides content by $95 \%$ through hydrolysis into cyanide by linamarase (Falade and Akingbala, 2008). The toxic cyanide is later removed by fermentation since it is soluble in water (Dziedzoave et al., 2006). Drying also contributes to the reduction of cyanide through evaporation.

From the point of view of food safety, besides the quality parameters of cassava flour determined and monitored by physicochemical analysis, the presence of potential toxic componets needs to be characterised, specially the cianogenic compounds and derivatives . For example, the $\mathrm{pH}$ should be in the acceptable range since it is an indicator of a good quality flour. A pH of 4 or less, indicates the inefficient fermentation, resulting to a sour taste in the product (Apea Bah et al., 2011). Thus, high quality flour should have a pH ranging between 6 and 7, a moisture content of 8-10\% and total cyanogens less than $10 \mathrm{mg} / \mathrm{kg} \mathrm{HCN}$ eq (Dziedzoave et al. 2006; Dziedzoave et al., 2003).

The quality of cassava for food and non-food uses is determined by analyzing both roots and flour by sensory and laboratory tests. Sensory tests are used in cassava processing to determine the quality of flour and cooked products using human senses. The main sensory test parameters include taste, aroma/flavor, color and texture of cassava flour, porridge or paste. Laboratory tests are used to determine physico-chemical and microbial characteristics in the flour and end products. These tests are also conducted for any newly developed or introduced cassava varieties to determine their acceptance levels towards the consumers. The production of cassava was significantly affected by diseases such as cassava mosaic and brown streak diseases (McCallum et al., 2017). The cassava value chain in Rwanda was also affected by the viral diseases, resulting in the shortage of the roots, hence increased prices at the market. The Government of Rwanda has immediately responded to the situation and introduced various cassava varieties that were developed from research institutions in partnering countries. Prior to release to the farmers, the newly introduced varieties were primarily tested and selected for resistance to diseases. The next process is to test the quality and safety of roots and flour as well as consumer acceptability. Therefore, this study was conducted to characterize the chemical profile and consumer acceptability of eight cassava varieties.

\section{Materials and Methods}

Sensory evaluation study was conducted for eight cassava varieties grown at Rubona station of Rwanda Agriculture and Animal Resources Development Board (RAB) in the Southern Province of Rwanda. The samples were analysed for chemical profile by the Rwanda Standards Board for Dry mater, titratable acidity, Cyanhydric Acid and crude fiber as detailled in chemical analysis.

\subsection{Sample Selection}

The samples were harvested from on-station trials conducted by Cassava Sub Program in Rubona station, Huye District, Southern Province of Rwanda. In total, eight experimental breeding lines were used in this study, 
namely NASE 14, NAROCASS 1, BULK 13, BULK 35, SEMAK 150/452, NDAMIRABANA/7, GAHENE/2 and MH95/0091. NASE 14, NAROCASS 1 and MH95/0091 are white fleshed and have dual purpose (sweet or bitter depending on the soil); BULK 35, SEMAK 150/452 and GAHENE are white and bitter, while BULK 13 and NDAMIRABANA/7 are yellow fleshed and bitter. These varieties were selected through Cassava Sub Program and the selection was based on the following parameters: disease resistance, yield (productivity in number and size of tubers) and quantity of cuttings produced as reported in 2019 by RAB cassava sub program . The maturity of these varieties was twelve months.

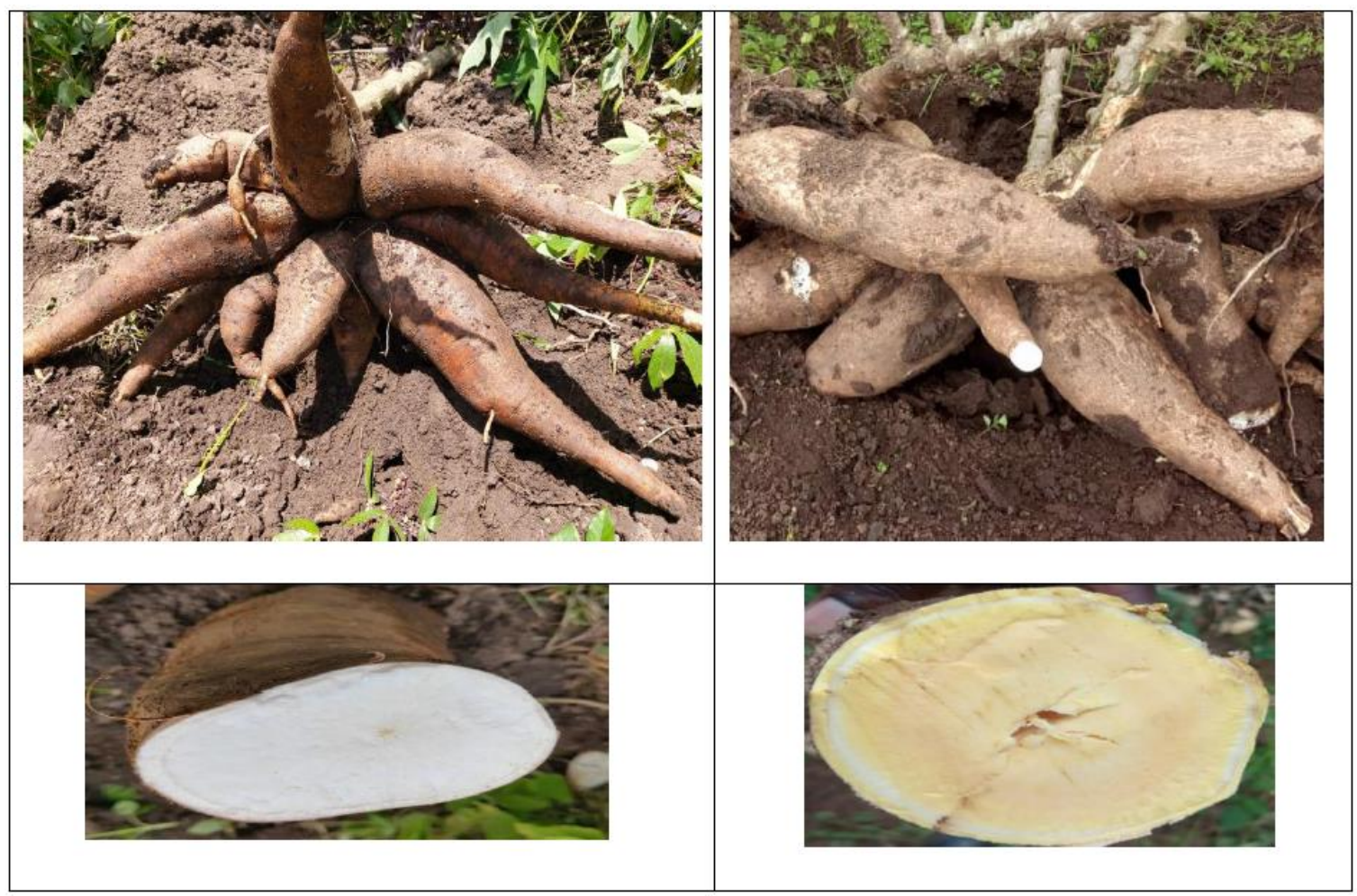

Figure 1. White cassava and yellow cassava

\subsection{Sample Preparation}

After the selection of varieties, the tubers were peeled, washed with tap water the same day and the tubers of each variety were divided into two parts. One of each part was grated and another as roots. One part of the grated cassava pulp was directly dried in a drying room and the other part was put in a bag and fermented in water tank for 72 hours. After 72 hours of fermentation followed the pressing and the drying of samples for 72 hours at 38$40^{\circ} \mathrm{C}$ in a drying room where the heat from firewood burned outside is distributed by tubes installed in the room. The other part of the roots or non-grated tubers was processed in the same procedure as the grated part. Four processing methods were used as follows: Cassava grated no fermented pressing, Cassava grated fermented pressing, Cassava roots no fermented pressing and Cassava roots fermented pressing. At each stage of processing, the samples were prepared for laboratory analysis (Dry mater, Acidity titratable, Cyanhydric Acid and crude fiber) and were kept in the refrigerator. The samples were submitted to Rwanda Standards Board (RSB) for those chemical analysis.

\subsection{Sensory Evaluation}

All the samples obtained by the four processing methods were dried to obtain flour. The flour from eight varieties was used to make cassava paste (Ugali), in Figure 2, for sensory evaluation in four replicates (according to the processing method used) by 30 members panelist each, for a total of 120 evaluators. A 9-point hedonic scale from like extremely $=9$ to dislike extremely $=1$ was used (Hashmi, 2007). The products were evaluated for the color, odor, taste, texture and general acceptability using an evaluation form. 


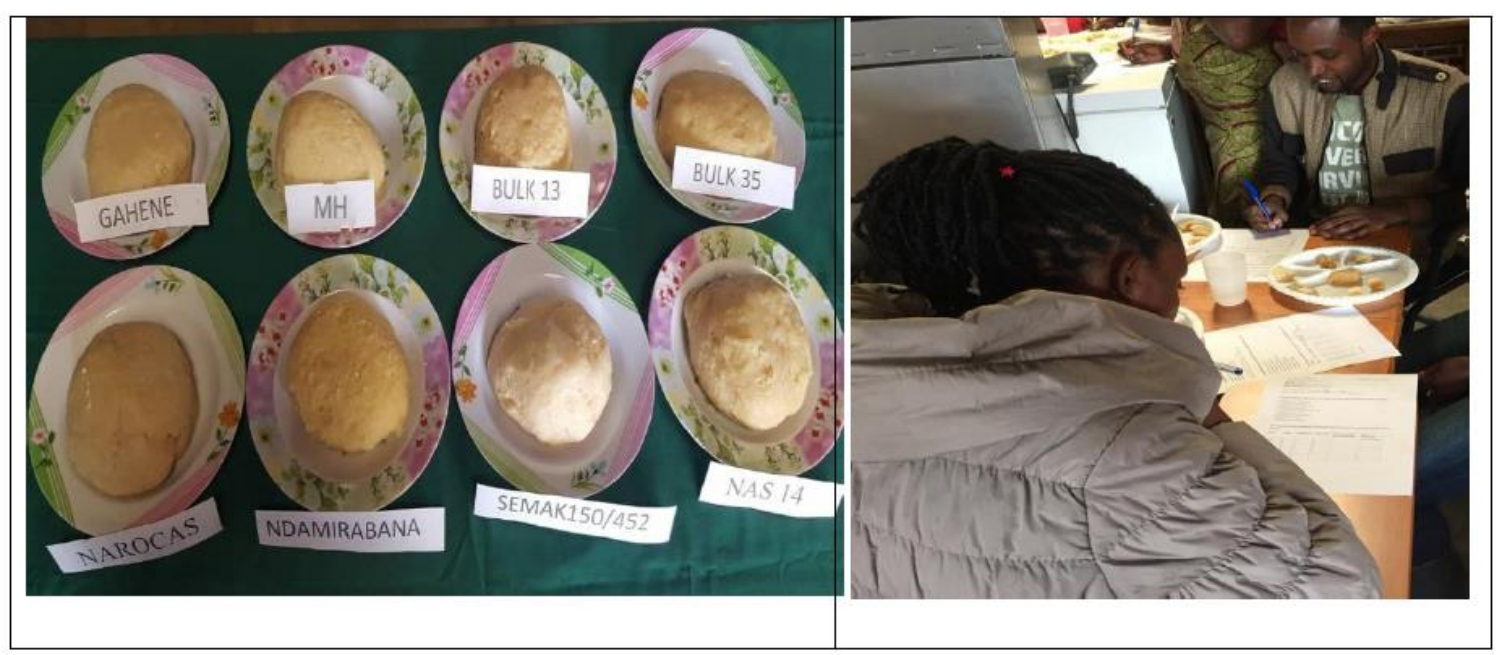

Figure 2. Cassava paste (Ugali) sensory evaluation

The codes used for tasting the different cassava paste (Ugali) were as follow in Table 1.

Table 1. Varieties and processing methods used for Ugali evaluated

\begin{tabular}{|c|c|c|c|}
\hline Codes & Processing Method 1 & Codes & Processing Method 2 \\
\hline 345 & $\begin{array}{l}\text { NASE } 14 \text { Cassava grated } \\
\text { fermented pressing dried }\end{array}$ & 543 & $\begin{array}{l}\text { NASE14 Cassava root fermented } \\
\text { pressing dried }\end{array}$ \\
\hline 479 & $\begin{array}{l}\text { NAROCASS 1Cassava } \\
\text { gratedfermented pressing dried }\end{array}$ & 974 & $\begin{array}{l}\text { NAROCASS1 Cassava } \\
\text { rootfermented pressing dried }\end{array}$ \\
\hline 510 & $\begin{array}{l}\text { BULK } 13 \text { Cassava grated } \\
\text { fermented pressing dried }\end{array}$ & 105 & $\begin{array}{l}\text { BULK 13Cassava root fermented } \\
\text { pressing dried }\end{array}$ \\
\hline 613 & $\begin{array}{l}\text { BULK } 35 \text { Cassava grated } \\
\text { fermented pressing dried }\end{array}$ & 316 & $\begin{array}{l}\text { BULK } 35 \text { Cassava root fermented } \\
\text { pressing dried }\end{array}$ \\
\hline 468 & $\begin{array}{l}\text { SEMAK 150/452 Cassava } \\
\text { grated fermented pressing dried }\end{array}$ & 864 & $\begin{array}{l}\text { SEMAK } 150 / 452 \text { Cassava root } \\
\text { fermented pressing dried }\end{array}$ \\
\hline 720 & $\begin{array}{l}\text { NDAMIRABANA/7 Cassava } \\
\text { grated fermented pressing dried }\end{array}$ & 270 & $\begin{array}{l}\text { NDAMIRABANA/7 Cassava root } \\
\text { fermented pressing dried }\end{array}$ \\
\hline 230 & $\begin{array}{l}\text { GAHENE/2 Cassava grated } \\
\text { fermented pressing dried }\end{array}$ & 320 & $\begin{array}{l}\text { GAHENE/2 Cassava root fermented } \\
\text { pressing dried }\end{array}$ \\
\hline 000 & $\begin{array}{l}\text { MH95/0091Cassava grated } \\
\text { fermented pressing dried }\end{array}$ & 200 & $\begin{array}{l}\text { MH95/0091 Cassava root fermented } \\
\text { pressing dried }\end{array}$ \\
\hline Codes & Processing Method 3 & Codes & Processing Method 4 \\
\hline 123 & $\begin{array}{l}\text { NASE } 14 \text { Cassava grated } \\
\text { no fermented pressing dried }\end{array}$ & 102 & $\begin{array}{l}\text { NASE14 Cassava root no fermented } \\
\text { pressing dried }\end{array}$ \\
\hline 456 & $\begin{array}{l}\text { NAROCASS 1Cassava grated } \\
\text { nofermented pressing dried }\end{array}$ & 202 & $\begin{array}{l}\text { NAROCASS1 Cassava root nofermented } \\
\text { pressing dried }\end{array}$ \\
\hline 678 & $\begin{array}{l}\text { BULK } 13 \text { Cassava grated } \\
\text { no fermented pressing dried }\end{array}$ & 302 & $\begin{array}{l}\text { BULK 13Cassava root no fermented } \\
\text { pressing dried }\end{array}$ \\
\hline 890 & $\begin{array}{l}\text { BULK } 35 \text { Cassava grated } \\
\text { no fermented pressing dried }\end{array}$ & 402 & $\begin{array}{l}\text { BULK } 35 \text { Cassava root no fermented } \\
\text { pressing dried }\end{array}$ \\
\hline 100 & $\begin{array}{l}\text { SEMAK 150/452 Cassava } \\
\text { grated no fermented pressing dried }\end{array}$ & 502 & $\begin{array}{l}\text { SEMAK } 150 / 452 \text { Cassava root no } \\
\text { fermented pressing dried }\end{array}$ \\
\hline 108 & $\begin{array}{l}\text { NDAMIRABANA/7 Cassava } \\
\text { grated no fermented pressing dried }\end{array}$ & 602 & $\begin{array}{l}\text { NDAMIRABANA/7 Cassava root no } \\
\text { fermented pressing dried }\end{array}$ \\
\hline 333 & $\begin{array}{l}\text { GAHENE/2 Cassava grated no } \\
\text { fermented pressing dried }\end{array}$ & 702 & $\begin{array}{l}\text { GAHENE/2 Cassava root no fermented } \\
\text { pressing dried }\end{array}$ \\
\hline 400 & $\begin{array}{l}\text { MH95/0091 Cassava grated no } \\
\text { fermented pressing dried }\end{array}$ & 802 & $\begin{array}{l}\text { MH95/0091 Cassava root no fermented } \\
\text { pressing dried }\end{array}$ \\
\hline
\end{tabular}




\subsection{Chemical Analysis}

Samples of cassava flour (64) from 8 varieties processed using diffent methods above and cassava roots (64) were submitted to RSB for chemical analysis, especialy dry mater, titratable acidity, cyanhydric acid and crude fiber. Rwanda Standards Board analysed the samples using their appropriate methods for the parameter tested. Briefly, Dry matter was determined, using the grinding mill, an amount slightly greater than that required for this test was grinded and amount of $5 \mathrm{~g}$ was weighed in a pre-dried crucible. The moisture content of the samples was determined based on adapted ISO 712 Fourth edition; 2009-11-15 (ISO, 2009) by drying the open dish containing the test portion together with the lid, in the oven controlled at $130 \pm 5^{\circ} \mathrm{C}$ for $120 \pm 10 \mathrm{~min}$. Then dry matter was calculated by subtracting obtained moisture content percentage from 100 . Titratable acidity was done referred to AOAC Official Method 947 (Horwitz \& Latimer, 2005). In fact, $20 \mathrm{ml}$ of cassava extract was measured into suitable dish where $2 \mathrm{ml}$ of phenolphthalein was added and titrate as rapid as possible with $0.05 \mathrm{M}$ sodium hydroxide to first persistent pink. Used volume of $0.1 \mathrm{M}$ sodium hydroxide was recorded and duplicate analysis was performed. HCN was analysed reffered to AOAC 915.05B, 18th edition, 2005, 49.11.02. Sample of $15 \mathrm{~g}$ was measured into $250 \mathrm{ml}$ conical flask containing $200 \mathrm{ml}$ of distilled water and allowed to stand for $3 \mathrm{~h}$ at $25^{\circ} \mathrm{C}$. Autolysis was carried out with the apparatus connected to a distiller. A $150 \mathrm{ml}$ of distillate was collected in $20 \mathrm{ml} 25 \%$ of $\mathrm{NaOH}$ solution and further diluted to $250 \mathrm{ml}$ with distilled water. Next, $100 \mathrm{ml}$ of the diluted distillate was mixed with $8.0 \mathrm{ml}$ of $6.0 \mathrm{~N} \mathrm{NH} 4 \mathrm{OH}$ and $2.0 \mathrm{ml}$ of $5 \% \mathrm{KI}$ indicator solution and titrated against $0.02 \mathrm{~N}$ AgNO3. The end point was indicated by a faint permanent turbid appearance. Crude fiber was determined by using NIRSTM DS2500-FOSS, DK-3400 Hilleroed Denmark. Analysis is based on direct measurements which consist of monochromator across the full spectral ranging from 850 to $2500 \mathrm{~nm}$ technology. By adding grounded samples in NIRS crucibles, then crude fiber results was directly obtained from software operating this NIRS equipment.

\subsection{Data Analysis}

The IBM SPSS Statistics for Windows, Version 22.0. Armonk, NY: IBM Corp. was used for the statistical analysis of the data. The comparison of means, by one-way ANOVA was done and the differences between treatments were considered significant at $\mathrm{P}$-value $<0.05$. Means were separated using least significance difference (LSD) post hoc tests.

\section{Results and Discussions}

\subsection{Characteristics of Sensory Evaluators}

The participants in the sensory evaluation of Ugali from eight cassava varieties were female (74\%) and male (26\%) The minimum age of participants was 21 , the average was $31.8 \pm 6.2$ years and the maximum was 55 years. The participants eat cassava at least once a week and maximum 7 times with an average of 4 times per week (3.52 \pm 1.56$)$.

\subsection{General Sensory Evaluation Attributes vs Processing Methods}

The sensory attributes of Ugali from 8 varieties was analysed for all processing methods used (1 Cassava grated fermented pressing dried, 2 Cassava root fermented pressing dried, 3 Cassava grated no fermented pressing dried and 4 Cassava root no fermented pressing dried) in Table 2.

Table 2. Means Color, Odor, Taste, Texture and General Acceptability vs Processing methods

\begin{tabular}{llllll}
\hline Processing methods & Color & Odor & Taste & Texture & General acceptability \\
\hline 1 & $6.93(1.51)^{*}$ & $6.68(1.51)^{*}$ & $6.89(1.59)^{*}$ & $6.97(1.63)^{*}$ & $6.88(1.55)^{*}$ \\
2 & $7.00(1.76)^{*}$ & $6.52(1.89)^{*}$ & $6.52(2.13)$ & $6.55(2.23)$ & $6.72(1.93)^{*}$ \\
3 & $6.60(2.07)^{*}$ & $6.35(2.02)$ & $6.34(2.39)$ & $6.75(2.31)^{*}$ & $6.48(2.23)$ \\
4 & $5.65(1.29)$ & $5.24(1.73)$ & $5.14(1.94)$ & $5.83(1.66)$ & $5.20(1.83)$ \\
\hline
\end{tabular}

*In the column indicates a significant difference at $\mathrm{P}<0.05$ level.

In general, the sensory attributes for the Ugali tested was significantly different $(\mathrm{P}<0.05)$. Ugali from fermented cassava was more preferred than the one from unfermented cassava. The Ugali from cassava roots not fermented was disliked slightly for all parameters color, odor, taste, texture and general acceptability. The first method of processing (Cassava grated fermented pressing dried) gave the most tasty Ugali followed by the second method used Cassava root fermented pressing dried. The method of grating was the more prefered for the white color than others. Grating cassava is a processing method to produce high quality flour as experimented by RAB processing Unit and IITA (Dziedzoave et al., 2006) 


\subsection{General Sensory Evaluation Attributes vs Varieties}

The eight varieties (1 NASE 14, 2 NAROCASS 1, 3 BULK 13, 4 BULK 35, 5 SEMAK 150/452, 6 NDAMIRABANA/7, 7 GAHENE/2 and 8 MH95/0091) were compared for all parameters evaluated in Table 3

Table 3. Means Color, Odor, Taste, Texture and General Acceptability vs Varieties

\begin{tabular}{llllll}
\hline Varieties & Color & Odor & Taste & Texture & General acceptability \\
\hline NASE 14 & $7.12(3.57)^{*}$ & $6.12(1.73)$ & $6.12(2.03)$ & $6.25(2.28)$ & $6.32(1.82)$ \\
NAROCASS 1 & $5.67(2.46)$ & $5.85(2.16)$ & $5.76(2.41)$ & $6.06(2.17)$ & $5.93(2.31)$ \\
BULK 13 & $6.35(1.89)$ & $6.28(1.94)^{*}$ & $6.85(2.03)^{*}$ & $7.12(1.84)^{*}$ & $6.67(1.99)$ \\
BULK 35 & $6.58(1.65)^{*}$ & $5.99(1.75)$ & $5.18(2.17)$ & $5.36(2.44)$ & $5.50(2.08)$ \\
SEMAK 150/452 & $7.15(1.74)^{*}$ & $6.65(1.66)^{*}$ & $6.73(1.86)^{*}$ & $6.86(1.81)^{*}$ & $6.87(1.85)^{*}$ \\
NDAMIRABANA/7 & $5.88(1.94)$ & $5.66(1.92)$ & $5.95(2.12)$ & $6.44(1.73)$ & $5.91(1.93)$ \\
GAHENE/2 & $7.30(1.59)^{*}$ & $6.74(1.83)^{*}$ & $6.95(1.83)^{*}$ & $7.16(1.65)^{*}$ & $7.06(1.78)^{*}$ \\
MH95/0091 & $6.39(1.65)$ & $6.34(1.81)$ & $6.28(2.02)$ & $6.97(1.49)^{*}$ & $6.37(1.81)$ \\
\hline
\end{tabular}

*In the column indicates a significant difference at $\mathrm{P}<0.05$ level.

The varieties were compared for the sensory attributes and the more preferred than others in general and other parameters (color, odor, taste and texture) were (7) GAHENE/2 and (5) SEMAK 150/452 followed by (3) BULK 13, (8) MH95/0091 and (1) NASE 14. The Ugali from (2) NAROCASS 1 and (6) NDAMIRABANA/7 were neither liked nor disliked, while the Ugali from (4) BULK 35 was disliked slightly. Among the preferred paste, BULK 13 was yellow fleshed and the variety can be promoted for the improvement of Vitamin $\mathrm{A}$ in the community. According to Ayetigbo (2018), there is an increase in adoption of bio fortified yellow-fleshed cassava and the widespread cultivation may outpace the white fleshed cassava in the future (Ayetigbo et al., 2018).

\subsection{Chemical Analysis of Cassava Flour}

Cyanide, acidity, Dry mater and crude fiber analysed in cassava flour samples from 8 varieties are summarized in the Table 4, on dry weight (d.w.).

Table 4. Cyanide Hydrogen, Titratable Acid, Dry matter and Crude fiber content in 8 varieties cassava flour

\begin{tabular}{lllll}
\hline Variety & $\begin{array}{l}\mathrm{HCN} \\
(\mathrm{mg} / \mathrm{kg})\end{array}$ & $\begin{array}{l}\text { Titratable Acidity } \\
(\mathrm{g} / 100 \mathrm{~g} \text { d.w. }\end{array}$ & $\begin{array}{l}\text { Dry matter } \\
(\mathrm{g} / 100 \mathrm{~g} \mathrm{d.w.})\end{array}$ & $\begin{array}{l}\text { Crude fiber } \\
(\mathrm{g} / 100 \mathrm{~g} \text { d.w. }\end{array}$ \\
\hline NAROCASS 1 & $1.17(0.27)$ & $0.074(0.03)$ & $86.9(0.51)$ & $3.47(0.0)$ \\
NASE 14 & $0.94(2.38)$ & $0.10(0.03)$ & $87.02(0.42)$ & $2.46(0.0)$ \\
SEMAK 150/452 & $0.93(0.25)$ & $0.12(0.03)$ & $88.04(0.49)^{*}$ & $3.87(0.0)^{*}$ \\
GAHENE/2 & $1.00(0.20)$ & $0.120(0.05)$ & $87.1(0.69)$ & $3.33(0.0)$ \\
BULK 35 & $1.12(0.26)$ & $0.13(0.04)$ & $87.43(0.37)$ & $3.81(0.0)^{*}$ \\
BULK 13 & $1.09(0.259)$ & $0.14(0.04)$ & $87.54(0.50)$ & $3.30(0.0)$ \\
NDAMIRABANA/7 & $1.384(0.53)$ & $0.164(0.05)^{*}$ & $88.26(0.25)^{*}$ & $3.17(0.0)$ \\
MH95/0091 & $1.45(0.60)$ & $0.14(0.03)$ & $87.51(0.32$ & $3.522(0.0)$ \\
\hline
\end{tabular}

*In the column indicates a significant difference at $\mathrm{P}<0.05$ level.

The content of HCN in the cassava flour was below the minimum lethal dose of $7 \mathrm{mg} / \mathrm{kg}$ d.w., according to the U.S. Department of Health and Human services, Public Health Service, Agency for Toxic Substances and Disease Registry (2006). The difference between varieties was significant for HCN, Acidity, dry matter and crude fiber tested. NASE 14 has the lowest HCN followed by Gahene/2 and Bulk 13

Comparison of the above parameters for the 4 processing methods was done as reported in Table 5 and the difference between processing methods was significant for $\mathrm{HCN}$, acidity and crude fiber determined on wet basis. 
Table 5. HCN, Titratable Acid, Dry matter and Crude fiber content in cassava flour by Processing methods

\begin{tabular}{lllll}
\hline Processing method & $\begin{array}{l}\mathrm{HCN} \\
(\mathrm{mg} / \mathrm{kg})\end{array}$ & $\begin{array}{l}\text { Titratable Acidity } \\
(\mathrm{g} / 100 \mathrm{~g} \text { d.w. }\end{array}$ & $\begin{array}{l}\text { Dry matter } \\
(\mathrm{g} / 100 \mathrm{~g} \mathrm{d.w.})\end{array}$ & $\begin{array}{l}\text { Crude fiber } \\
\text { (g/100g d.w.) }\end{array}$ \\
\hline Cassava grated fermented pressing dried & $0.99(0.27)$ & $0.085(0.02)$ & $87.4(0.45)$ & $3.33(0.0)$ \\
Cassava grated no fermented pressing dried & $1.12(0.32)^{*}$ & $0.14(0.04)^{*}$ & $87.4(0.48)$ & $4.04(0.0)^{*}$ \\
Cassava root fermented pressing dried & $1.00(0.17)$ & $0.12(0.04)$ & $87.58(0.73)$ & $2.85(0.0)$ \\
Cassava root no fermented pressing dried & $1.42(0.53)^{*}$ & $0.15(0.04)^{*}$ & $87.53(0.81)$ & $3.25(0.0)$ \\
\hline
\end{tabular}

*In the column indicates a significant difference at $\mathrm{P}<0.05$ level.

Cassava grated and root fermented and pressed has low cyanide, acidity and crude fiber than the other methods used. This is consistent with the results for sensory evaluation where the paste from the processing method was more appreciated. The cyanide is eliminated especially by grating, the cassava tissues are disrupted, the linamarase enzyme make contact with the cyanogenic component and breaks them down into hydrogen cyanide volatile and acetone soluble into water. Thus, grating, dewatering, drying remove the cyanide (Padmaja, 1995)

\subsection{Chemical Analysis of Cassava Roots}

Chemical analysis of cassava varieties was conducted, and the results are presented in table 6 , on fresh weight (f.w.). Among the analyzed parameters, cyanide is significant for the safety of consumers. The results show that there is no significant difference $(\mathrm{P}>0.05)$ between the eight varieties evaluated.

Table 6. Chemical composition of fresh cassava roots (HCN, Titratable acid, Dry matter and crude fiber)

\begin{tabular}{llllll}
\hline Variety & $\begin{array}{l}\mathrm{HCN} \\
(\mathrm{mg} / \mathrm{kg})\end{array}$ & $\begin{array}{l}\text { Titratable } \\
\text { Acidity } \\
\text { (g/100g f.w. })\end{array}$ & $\begin{array}{l}\text { Dry matter } \\
(\mathrm{g} / 100 \mathrm{~g} \mathrm{f.w} .)\end{array}$ & $\begin{array}{l}\text { Crude fiber on dry } \\
\text { matter basis } \\
\text { d.w. })\end{array}$ & $\begin{array}{l}\text { Crude fiber } \\
\text { (g/100g On wet basis } \\
\text { (g/100g f.w. })\end{array}$ \\
\hline NAROCASS 1 & $3.00(0.84)$ & $0.38(0.18)^{*}$ & $47.22(5.02)$ & $1.43(0.96)$ & $2.84(1)$ \\
NASE 14 & $3.64(1.64)^{*}$ & $0.273(0.11)$ & $50.63(2.97)^{*}$ & $2.37(1.14)^{*}$ & $4.53(2)^{*}$ \\
SEMAK 150/452 & $4.23(1.74)^{*}$ & $0.18(0.21)$ & $49.7(6.56)^{*}$ & $1.25(0.93)$ & $2.41(1)$ \\
GAHENE/2 & $3.85(1.94)^{*}$ & $0.249(0.16)$ & $50.1(5.47)^{*}$ & $1.03(0.37)$ & $2.08(0)$ \\
BULK 35 & $2.48(0.62)$ & $0.23(0.14)$ & $42.63(5.57)$ & $1.12(0.56)$ & $2.08(1)$ \\
BULK 13 & $2.65(0.57)$ & $0.19(0.12)$ & $48.04(4.21)$ & $1.57(0.40)$ & $2.08(0)$ \\
NDAMIRABANA/7 & $3.11(0.73)$ & $0.27(0.18)$ & $45.05(5.80)$ & $0.88(0.55)$ & $2.08(1)$ \\
MH95/0091 & $2.93(1.39)$ & $0.21(0.18)$ & $48.92(6.52)$ & $1.02(0.47)$ & $2.08(0)$ \\
\hline
\end{tabular}

*In the column indicates a significant difference at $\mathrm{P}<0.05$ level.

The HCN content ranges between 2.477 and $4.228 \mathrm{mg} / \mathrm{kg}$, which less than the allowed $10 \mathrm{mg} / \mathrm{kg}$ for human safety (EAC, 2010; WHO, 2012). These values According to CODEX (2013), sweet cassava varieties have less than $50 \mathrm{mg} / \mathrm{kg}$ (Fresh weight basis) of HCN, while bitter cassava varieties have more than $50 \mathrm{mg} / \mathrm{kg}$. However, the results showed that all the evaluated cassava varieties can be classified as sweet varieties. Among the collected samples, the varieties BULK 35 and BULK 13 were identified as bitter cassava; yet the results showed that they have less HCN content of 2.477 and $2.649 \mathrm{mg} / \mathrm{kg}$ respectively.

The total titratable acidity plays an important role in taste quality of cassava. It is influenced by the variety and growing conditions among others. This is shown by the significance difference $(\mathrm{P}<0.05)$ in titratable acidity between the varieties, ranging between 0.1867 and $0.3850 \%(\mathrm{w} / \mathrm{w})$ as shown in table 6 .

The nutritional and economic qualities are determined by the dry matter content of fresh tubers. Teye et al. (2011) indicated that high quality cassava tubers contain more than $30 \%$ of dry matter. In this study, the results showed that the eight varieties contain slightly high dry matter ranging between 42.63 and $50.63 \%(\mathrm{w} / \mathrm{w})$, with more than $46 \%$ to six varieties. However, the previous studies showed that the dry matter ranged between 27 and $46 \%$ in cassava varieties collected in Ivory Coast (Bakayoko et al., 2012), 22 and $49 \%$ in Nigeria, and 9-46 in Tanzania (Oluwole et al., 2007). Crude fiber is another nutritional quality of cassava for human consumption. The results showed that the crude fiber content in cassava tubers was significantly different $(\mathrm{P}<0.05)$ among the eight varieties, ranging between 2.08 and $4.528 \%$ on wet basis. 
Table 7. Effect of cassava processing method on chemical composition (HCN, Titratable acid, Dry matter and crude fiber)

\begin{tabular}{llllll}
\hline Processing method & $\begin{array}{l}\text { HCN } \\
(\mathrm{mg} / \mathrm{kg} \text { f.w.) }\end{array}$ & $\begin{array}{l}\text { Titratable } \\
\text { Acidity } \\
\text { (g/100g f.w) }\end{array}$ & $\begin{array}{l}\text { Dry matter } \\
\text { (g/100g f.w) }\end{array}$ & $\begin{array}{l}\text { Crude fiber on } \\
\text { dry matter basis } \\
\text { (g/100g d.w) }\end{array}$ & $\begin{array}{l}\text { Crude fiber on } \\
\text { wet basis } \\
\text { (g/100g f.w })\end{array}$ \\
\hline Cassava grates fermented & $3.03(0.94)$ & $0.25(0.10)$ & $46.84(3.10)$ & $0.84(0.48)$ & $1.79(0.48)$ \\
Cassava un fermented grates & $3.07(1.32)$ & $0.12(0.1)$ & $52.02(4.26)^{*}$ & $1.84(1.19)^{*}$ & $3.50(1.19)^{*}$ \\
Cassava root fermented & $3.21(1.29)$ & $0.36(0.09)^{*}$ & $41.6(3.85)$ & $0.84(0.32$ & $2.03(0.32)$ \\
Cassava unfermented root & $3.63(0.76)$ & $0.27(0.11)$ & $50.68(4.88)^{*}$ & $1.81(1.09)^{*}$ & $3.54(1.09)^{*}$ \\
\hline
\end{tabular}

*In the column indicates a significant difference at $\mathrm{P}<0.05$ level.

The methods of cassava processing produce products with slight difference in cyanide content. Grating as one of the steps in cassava processing, reduces the amount of cyanide.

Similarly, fermentation reduces the cyanide content at a slight level. However, the statistical analysis showed that processing methods do not differ significantly $(\mathrm{p}>0.005)$ in reduction of cyanide in cassava. The results of this study differ with the literature. For example, fermentation removes some amount of cyanide due to hydrolysis of cyanogenic glycosides. Moreover, grating of fresh cassava tubers helps to reduce the cyanide.

The four methods of cassava processing showed significant different levels $(\mathrm{P}<0.005)$ of titratable acidity. In this study, fermented cassava roots had more titratable acidity $(0.3584 \%$, w/w) than non-fermented roots had $(0.267 \%$ $\mathrm{w} / \mathrm{w}$ ) as shown in table 7 . This was similarly observed in grating method of cassava processing with $0.2538 \%$, $\mathrm{w} / \mathrm{w}$ in fermented grates and $0.1202 \%, \mathrm{w} / \mathrm{w}$ in unfermented grates. In addition, grating of cassava reduces the level of titratable acidity with and without fermentation.

Fermentation and non-fermentation methods produce different significant $(\mathrm{P}<0.005)$ levels of crude fiber. For example, fermented grates had $1.796 \%(\mathrm{w} / \mathrm{w})$ of crude fiber, while unfermented grates had $3.501 \%(\mathrm{w} / \mathrm{w})$. Similarly, fermented roots had $2.027 \%(\mathrm{w} / \mathrm{w})$ of crude fiber, while unfermented roots had $3.537 \%(\mathrm{w} / \mathrm{w})$. However, the results showed that grating does not affect the level of crude fiber.

The fermentation in water reduces the dry matter content in both cassava grates and roots. The table 7 shows that fermented grates, unfermented grates, fermented roots and unfermented roots had $46.84 \%, 52.02 \%, 41.60 \%$ and $50.68 \%(\mathrm{w} / \mathrm{w})$ respectively. The loss of dry matter due to fermentation may result to hydrolysis of starch into soluble sugars which are taken away with water. The study also revealed that grating of cassava roots does not affect the dry matter content.

Based on the research findings, the study aimed at sensory evaluation and chemical analysis of eight cassava varieties. From the chemical analysis, the 8 varieties flour from the 4 processing methods had the acceptable acidity and the NASS 14, Gahene and Bulk 13 had the lowest cyanide hydrogen. These varieties with lowest cyanogenic are also among ones preferred in sensory evaluation. Nwachukwu (1997) reported that a major problem in the use of cassava is the cyanogenic glucosides which upon hydrolysis produce toxic hydrogen cyanide. He stated then that consumption of improperly processed cassava food may lead to goiter and cretinism from the ingestion and accumulation of $\mathrm{HCN}$ in the body. Hence, the selection of cassava varieties that are not cyanogenic or low cyanogenic content is important. This study showed that fermentation in water reduces the dry matter content in both cassava grates and roots. Also, cassava products depend on the dry matter content of the tubers; thus it is important to have high dry matter, since such food products are usually marketed in dry form (Nwachukwu et al., 1997). According to Adebowale (2008), there is significant interaction between variety and pasting viscosity. The proximate, physiological and sensory parameters could be major criteria in selecting the varieties that will yield the best product in cassava foods (Adebowale et al., 2008). These suggest that if the varieties used in processing cassava into their product are carefully selected, the farmers will be able to know which species would be of greatest demand and thus minimize loss resulting from planting of cyanogenic varieties.

\section{Conclusion}

Cassava lines investigated during this study were found to be safe for human consumption given their low levels of $\mathrm{HCN}$, which is toxic. Further reduction in the latter was observed as a result of processing fresh roots into flours, with grating and fermentation having a significant effect. The cassava paste from the flour obtained by the processing method of cassava grated fermented pressed and dried was the most preferred paste than the one from other three processing methods used. The eight cassava varieties introduced in Rwanda were compared for color, 
odor, taste and texture, and SEMAK, Gahene/2, Bulk 13, MH 95/0091 and NASE 14 were the most preferred. From the chemical analysis, the 8 varieties flour from the 4 processing methods had the acceptable acidity and the NASE 14, Gahene/2 and Bulk 13 had the lowest cyanide hydrogen. The high dry matter content in the varieties studies is an important trait economically, for farmers and processors, since this can be an indication of high yield in terms of flour production and turnover.

\section{Acknowledgment}

This study was funded by The Post-Harvest and Agribusiness Support Project (PASP), Rwanda. The support from Rwanda Standards Board and Rwanda Agriculture and Animal Resources Development Board is highly appreciated.

\section{References}

Adebowale, A. A., Sanni, L. O., \& Onitilo, M. O. (2008). Chemical composition and pasting properties of tapioca grits from different cassava varieties and roasting methods. African Journal of Food Science, 2, 077-082.

Apea-Bah, F. B., Oduro, I., Ellis, W. O., \& Safo-Kantanka, O. (2011). Factor Analysis and Age at Harvest Effect on the Quality of Flour from Four Cassava Varieties. World Journal of Dairy \& Food Sciences, 6, 43-54.

Ayetigbo, O., Latif, S., Adebayo Abass, A., \& Joachim Müller, J. (2018) Comparing Characteristics of Root, Flour and Starchof Biofortified Yellow-Flesh and White-Flesh Cassava Variants, and Sustainability Considerations: A Review. Sustainability, 10, 3089. https://doi.org/10.3390/su10093089

Bakayoko, S., Kouadio, K. K. H., Soro, D., Tschannen, A., Nindjin, C., Dao, D., \& Girardin, O. (2012). Rendements en tubercules frais et teneurs en matière sèche de soixante-dix nouvelles variétés de manioc (Manihot esculenta Crantz) cultivées dans le centre de la Côte d'Ivoire. Journal of Animal \& Plant Sciences, 14(2), 1961-1977. https://doi.org/10.4314/jab.v61i0.85595

Balagopalan, C., Padmaja, G., Nanda, S. K., \& Moorthy, S. M. (1988). Cassava in food, feed, and industry. CRC Press, Boca Raton, Florida USA.

Breuninger, W. F., Piyachomkwan, K., \& Sriroth, K. (2009). Tapioca/Cassava Starch: Production and use. In J. BeMiller \& R. Whistler (Eds.), Starch chemistry and technology (pp. 541-568). Third edition. Academic Press. https://doi.org/10.1016/B978-0-12-746275-2.00012-4

CODEX. (2013). Standard for biter cassava, CODEX STAN 300-2010. Amended in 2013.

Dziedzoave, N. T., Graffham, A. J., \& Boateng, E. O. (2003). Training manual for the production of high quality cassava flour. Food Research Institute (FRI), Accra, Ghana.

Dziedzoave, N. T., Abass, A. B., Amoa-Awua, W. K. A., \& Sablah, M. (2006). Quality Management Manual for Production of High Quality Cassava Flour. International Institute of Tropical Agriculture, Training manual. pp. 68. Retrieved from https://hdl.handle.net/10568/91815

EAC. (2010). Cassava flour-specification. East African Standard EAS 740:2010.

Falade, K., \& Akingbala, J. (2008). Improved Nutrition and National Development through the Utilization of Cassava in Baked Foods. In G. L. Robertson \& J. R. Lupien (Eds.), Using Food Science and Technology to Improve Nutrition and Promote National Development. International Union of Food Science \& Technology, chapter, 10, 1-12.

Falade, K., \& Akingbala, J. (2010). Utilization of Cassava for Food. Food Reviews International, 27(1), 51-83. https://doi.org/10.1080/87559129.2010.518296

Hashmi, I. (2007). Sensory evaluation techniques. 18th Annual IAOM Conference (MEA District) Muscat-Oman. Retrieved from http://www.iaom-mea.com/EduMat/...Tech10-AGF-IAOM-Muscat-07.pdf

Horwitz, W., \& Latimer, J. W. (2005). Official methods of analysis of AOAC International (18th ed.). Current through Revision 2, 2007. AOAC International, Maryland, USA.

ISO. (2009). Cereals and cereal products: Determination of moisture content (4th ed.). Reference method, ISO 712, International Standard, Switzerland.

McCallum, E. J., Anjanappa, R. B., \& Gruissem, W. (2017). Tackling agriculturally relevant diseases in the staple crop cassava (Manihot esculenta). Current Opinion in Plant Biology, 38, 50-58. https://doi.org/10.1016/j.pbi.2017.04.008

Montagnac, J. A., Davis, R. C., \& Tanumihardjo, S. A. (2009). Nutritional value of Cassava for use as a staple 
food and recent advances for improvement. Comprehensive reviews in food science and food safety, 8 , 181-194. https://doi.org/10.1111/j.1541-4337.2009.00077.x

Møller, B. L. (2010). Functional diversifications of cyanogenic glucosides. Current Opinion in Plant Biology, 13, 338-347. https://doi.org/10.1016/j.pbi.2010.01.009

Nwachukwu, E. C., Mbanaso, E. N. A., \& Ene, L. S. O. (1997). Improvement of cassava for high dry matter, starch and low cyanogenic glucoside content by mutation induction. International Atomic Energy Agency (IAEA). IAEA-TECDOC-951.

Oluwole, O. S. A., Onabolu, A. O., Mtunda, K., \& Mlingi, N. (2007). Characterization of cassava (Manihot esculenta Crantz) varieties in Nigeria and Tanzania, and farmers' perception of toxicity of cassava. Journal of Food Composition and Analysis, 20(7), 559-567. https://doi.org/10.1016/j.jfca.2007.04.004

Oyewole, O. (1995). Application of Biotechnology to cassava processing in Africa. In T. Agbor Egbe, A. Brauman, D. Griffon \& S. Trèche (Eds.), Transformation Alimentaire du Manioc. ORSTOM.

Padmaja, G. (1995) Cyanide detoxification in cassava for food and feed use. Critical Reviews in Food Science and Nutrition, 35(4), 299-339. https://doi.org/10.1080/10408399509527703

Quaye, W., Gayin, J., Yawson, I., \& Plahar, W. A. (2009). Characteristics of various cassava processing methods and the adoption requirements in Ghana. Journal of Root Crops, 35(1), 59-68

Taofik, A. S., Buliyaminu, A. A., Bashira, W., Lateef, O., Adebayo, B., \& Cassava, A. (2016). Flour and Starch: Processing Technology and Utilization. In K. S. Harish, Y. N. Nicolas, S. Rekha \& K. Pragati (Eds.), Tropical Roots and Tubers (pp. 415-450). https://doi.org/10.1002/9781118992739.ch10a

Teye, E., Asare, A. P., Amoah, R. S., \& Tetteh, J. P. (2011). Determination of dry matter content of Cassava tubers (Manihot esculenta Crantz) in the Coastal Savannah zone of Ghana using specific gravity method. ARPN Journal of Agricultural and Biological Science, 6(11), 1-28.

Uyoh, E. A., Ntui, V. O., \& Udoma, N. N. (2009). Effect of local cassava fermentation methods on some physiochemical and sensory properties of FUFU. Pakistan Journal of Nutrition, 8(8), 1123-1125. https://doi.org/10.3923/pjn.2009.1123.1125

Wangpor, J., Prayoonyong, P., Sakdaronnarong, C., Sungpet, A., \& Jonglertjunya, W. (2017). Bioethanol production from cassava starch by enzymatic hydrolysis, fermentation and ex-situ nanofiltration. Energy Procedia, 138, 883-888. https://doi.org/10.1016/j.egypro.2017.10.116

WHO. (2012). Cyanogenic glycosides, in: Safety Evaluation of Certain Food Additives and Contaminants. 74th Meeting of the Joint FAO/WHO Expert Committee on Food Additives.

\section{Copyrights}

Copyright for this article is retained by the author(s), with first publication rights granted to the journal.

This is an open-access article distributed under the terms and conditions of the Creative Commons Attribution license (http://creativecommons.org/licenses/by/4.0/). 